\title{
Assessment of quality of water and sediments in small reservoirs in Southern Poland - A case study
}

\author{
Bogusław Michalec $^{1^{\dagger}}$, Agnieszka Cupak ${ }^{2}$ \\ ${ }^{1}$ Department of Water Engineering and Geotechnics, University of Agriculture in Cracow, Poland \\ ${ }^{2}$ Department of Sanitary Engineering and Water Management, University of Agriculture in Cracow, Poland
}

\begin{abstract}
The paper presents an attempt to forecast heavy metal pollution of sediments of four designed reservoirs in southern Poland. For this purpose, concentration of dissolved heavy metals (lead, cadmium and nickel) was determined in water of watercourses on which the designed reservoirs will be constructed and also in sediments and water flowing into six reservoirs that are already in use. Based on the results of the heavy metal concentrations of six exploited reservoirs, a relationship was developed between heavy metal concentration in the sediment as a function of the concentration of these metals in the inflowing water. Using these relationships, the forecast concentrations of these metals in the sediments of the designed reservoirs were estimated. The mean concentrations of these metals in the planned reservoirs were $20.5 \mathrm{mg}^{-1} \mathrm{~kg}^{-1} \mathrm{fod} 3.4$ $\mathrm{mgkg}^{-1}$ for cadmium and $14.8 \mathrm{mgkg}^{-1}$ for nickel. No dangerous pollution of analyzed metal of water inflows to the planned reservoirs was found. The calculated geoaccumulation index indicates that in terms of the lead and nickel concentrations, sediments in the planned reservoirs will be unpolluted to moderately polluted, while for cadmium concentrations - they will be moderately to strongly polluted.
\end{abstract}

Keywords: Bottom sediment, Forecast of heavy metal concentration, Heavy metals, Sediment quality guidelines, Small reservoirs

\section{Introduction}

The construction of small reservoirs is one of the elements of actions to improve the condition as well as to increase and reconstruct resources. They provide protection against floods, serve as main source of water supplies, enable the usage of water energy, serve as water transport routes and storage volumes for irrigation of agricultural soils, they allow tourist-recreational services, serve as fish ponds and significantly contribute to improve the quality of waterbodies [1].

Most frequently, reservoirs are classified based on their capacity. According to the World Commission on Reservoirs [2] small reservoir capacity ranges from $50,000 \mathrm{~m}^{3}$ to 1 million $\mathrm{m}^{3}$. In Poland, it has been assumed that a small reservoir has a total capacity not exceeding 5 million $\mathrm{m}^{3}$ [3]. The bottom limit of the criterion was the damming height, which cannot be less than $1.5 \mathrm{~m}$, and the volume not less than $20,000 \mathrm{~m}^{3}$. A similar classification in terms of capacity was adopted in Romania [4]. In Great Britain, on the other hand, a small reservoir is considered to have a capacity of less than 1 million $\mathrm{m}^{3}$ and closes catchments with an area of not more than $25 \mathrm{~km}^{2}$ [5]. According to [6], small reservoirs have a capacity of 1 to 10 million $\mathrm{m}^{3}$. Small reservoirs are characterized by high silting intensity. The reduction of the capacity of reservoirs as a result of mineral sedimentation is the main factor limiting their exploitation. Especially for small ponds, the sedimentation can become a severe problem as the rate of siltation is generally much higher in comparison to large reservoirs [7]. As a result of intensive siltation rate of small reservoirs, their frequent desilting is necessary [8]. A general life-span of small reservoirs is over a dozen years $[9,10]$ or several dozen years $[11,12]$. The uncontaminated mineral material extracted from these reservoirs is very often used for agricultural or earth works carried out in the catchment area. The reservoir sediments can be a good material for the reclamation of industrially degraded areas. In the case of such method of management of chemically contaminated sediment, there is a risk of soil pollution. Determining the degree of sediment pollution, among others with heavy metals, is important not only because of the assessment of the possible use of the extracted sediment. The sediment pollution assessment can also be helpful in assessing the state of the environment [13-16].
This is an Open Access article distributed under the terms of the Creative Commons Attribution Non-Commercial License (http://creativecommons.org/licenses/by-nc/3.0/) which permits unrestricted non-commercial use, distribution, and reproduction in any medium, provided the original work is properly cited.

Copyright (C) 2022 Korean Society of Environmental Engineers
Received November 27, 2020 Accepted January 30, 2021

${ }^{\dagger}$ Corresponding author

E-mail: rmmichbo@cyf-kr.edu.pl

Tel: +48 126624052

ORCID: 0000-0002-0402-3416 
The dams of small reservoirs usually close small-scale catchments. Small reservoirs contribute to the formation of renewable water resources, which in small catchments, located in areas with low anthropogenic impact, are chemically affected by environmental conditions that are similar to natural [17]. In contrast, catchments with strong anthropogenic pressure of urban and suburban areas are characterized by poorer water quality. The increased imperviousness and the resulting contaminated stormwater will also deteriorate the water quality in urban areas [18, 19]. Also, rainwater from urbanized areas is significantly contaminated with heavy metals [20]. Therefore, the location of the reservoir in a catchment area with high anthropogenic pressure may cause the accumulation of sediments with increased concentrations of harmful substances, including heavy metals.

Sediments accumulate contaminants and serve as sources of pollution to the ecosystems they are connected with. These pollutants, accumulated in reservoirs, are pathogens, nutrients, metals, and organic chemicals. Burton [21] stated that if the loading of these contaminants into the waterways is large enough, the sediments may accumulate excessive amounts of contaminants that directly and indirectly disrupt the ecosystem, causing significant contamination and loss of desirable species. The determination of the concentration of these substances in sediment and water is presented in many studies, where the level of contamination, usually with heavy metals, is assessed [22-24], as well as their spatial distribution, temporal variability, different chemical forms in sediments determining their mobility, potential toxicity and bioavailability [25, 26]. According to Sojka et al. [24] despite the numerous research results available, there are some deficiencies that still need attention. Sojka et al. [24] also add after Wang et al. [27], that the majority of research results concern a given reservoir, while there is few research covering the variability of heavy metal content in a group of reservoirs. Among these studies there are also those whose results enable forecasting of heavy metal contamination of sediments in reservoirs.

Forecasting models are developed to determine heavy metal contamination mainly for rivers, their estuaries and drainage systems from catchment area. One such model is geographically weighted regression (GWR) that was developed to overcome these disadvantages of traditional regression models [28]. This model has been widely employed in water pollution management and aids in contamination prediction and risk assessment. The GWR model was used for spatial prediction of trace metal concentrations in surface and ground waters based on spatial predictors in Pakistan [29]. The statistical models developed by Bak et al. [30] for forecasting the quality of stormwater sediments, in which artificial neural networks are used (multilayer perceptron neural networks), showed varied impacts of catchment characteristics and atmospheric conditions on the chemical composition of sediments. The authors of these investigations concluded that the concentration of heavy metals ( $\mathrm{Ni}, \mathrm{Mn}, \mathrm{Co}, \mathrm{Zn}, \mathrm{Cu}, \mathrm{Pb}$, and $\mathrm{Fe}$ ) in sediments was far more affected by catchment characteristics (land use, length of the drainage system) than by atmospheric conditions. Yao et al. [31] based on data collected at eleven sites along two rivers feeding the Taihu Basin, China, developed a relationship between the concentration of five metals (aluminum (Al), titanium (Ti), nickel (Ni), vanadium $(\mathrm{V})$, lead $(\mathrm{Pb})$ ) and turbidity. The linear regression equa- tions were applied to estimate the metal concentration using online turbidity data. The USC (Urban Stormwater Contaminant) model combines information from several underlying models, including a catchment model (based on GLEAMS) for predicting daily sediment runoff, and an estuary hydrodynamics/sediment-transport mode [32]. The USC model predicts the accumulation of heavy metals in estuary bed sediments. Ayaz and Khan [33] developed the NARX-NN model (nonlinear auto regressive exogenous neural network model) to predict and quantify the presence of pollutants, particularly heavy metals such as chromium $(\mathrm{Cr})$, copper $(\mathrm{Cu})$, lead $(\mathrm{Pb})$, nickel $(\mathrm{Ni})$ and zinc $(\mathrm{Zn})$, in sea water of the Karachi coastal area along the Karachi harbor at six locations. These models could be used to forecast heavy metal contamination of sediments in water bodies. However, this has not been proven. The development of models forecasting heavy metal contamination of sediment in reservoirs will make it possible to predict the risk of environmental contamination in case of further exploitation of existing and planned reservoirs.

This paper presents an attempt to forecast the heavy metal pollution of sediments in the designed four small reservoirs located in urbanized areas. The forecast contamination of sediments that will accumulate in these reservoirs was determined based on the developed correlation dependencies of the metal concentration in the sediment and water flowing into the reservoir. The correlation dependencies were developed on the basis of the results of tests on sediments collected from the existing and operated six small reservoirs, as well as based on the analyzes of water flowing into these reservoirs. Lead $(\mathrm{Pb})$, cadmium $(\mathrm{Cd})$ and nickel (Ni) concentrations were determined in the collected sediment and water samples. The level of contamination with these metals was determined for water flowing into the existing and designed reservoirs, the level of sediment contamination with these metals within the existing reservoirs was also determined. Finally, we estimated the level of sediment contamination with these metals in the designed reservoirs. The proposed approach will allow the estimation of the total heavy metal content in the sediments of the designed reservoirs.

\section{Materials and Methods}

\subsection{Study Area}

The designed four small reservoirs will be constructed in the vicinity of the city of Kraków (Fig. 1). On the other hand, the existing small reservoirs, which were included in the study (Krempna, Zesławice, Maziarnia, Cierpisz, Niedźwiadek and Narożniki) are located in the catchments of the upper Vistula basin [34] (Fig. 1).

The capacity of the examined reservoirs ranged from 34 to 3,860 $10^{3} \mathrm{~m}^{3}$ (Table 1). The Krempna reservoir on the Wisłok River was built in 1972. As a result of intensive silting (of 30\%), the reservoir was dredged after fifteen years of operation. The Zesławice reservoir on the Dłubnia river was put into operation in 1966. After seventeen years it was dredged, because after this period the siltation rate was over 50\%. The Cierpisz reservoir on the Tuszymka River was built in 1956. After 34 years of operation, in 1990, it was dredged 

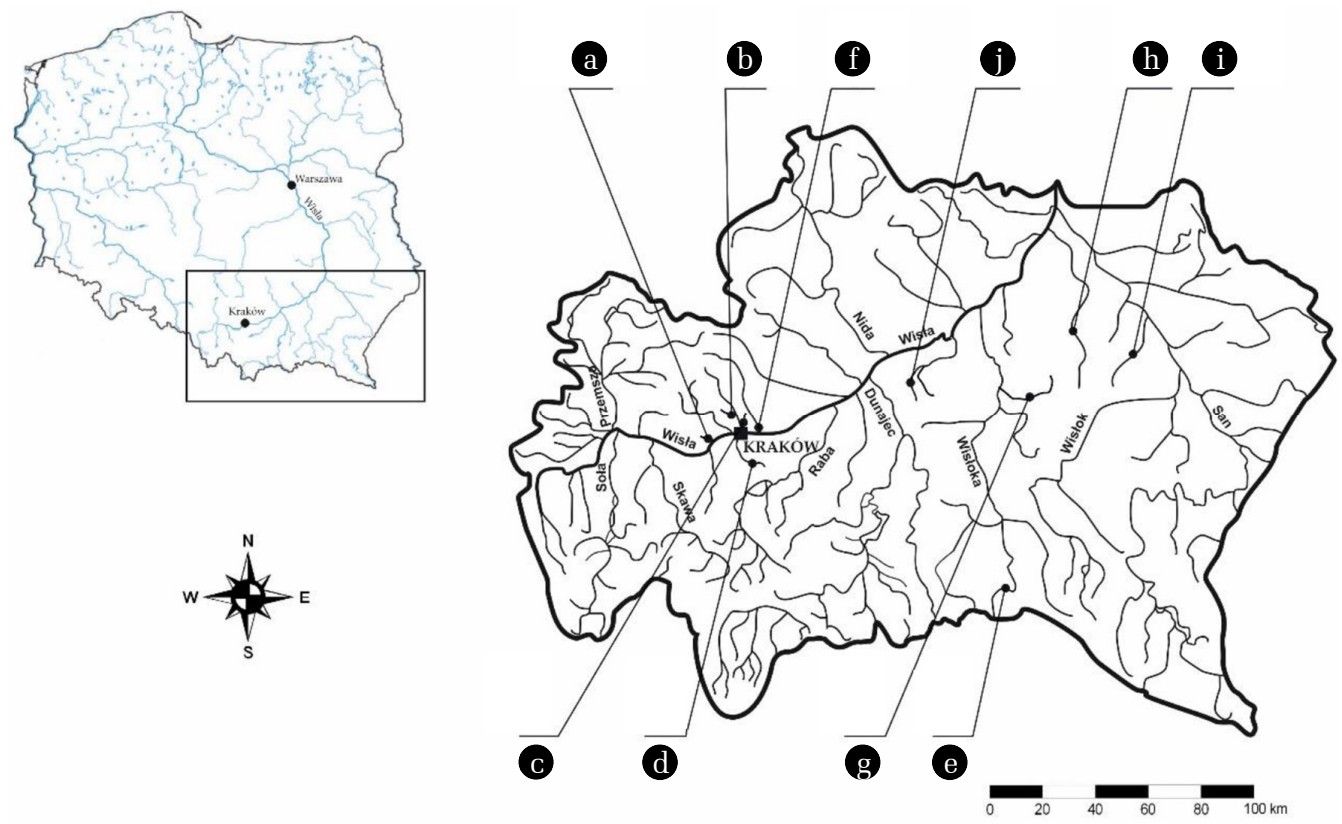

Fig. 1. Location of planed small reservoirs: (a) Piekary, (b) Tonie, (c) Węgrzce, (d) Janowice, and operated small reservoirs: (e) Krempna, (f) Zesławice-2, (g) Maziarnia, (h) Cierpisz, (i) Niedźwiadek, (j) Narożniki.

Table 1. Comparison of Basic Parameters of the Planned Small Reservoirs

\begin{tabular}{|c|c|c|c|}
\hline Reservoir/Watercourse & $\begin{array}{l}\text { Reservoir capacity } \\
\qquad V\left[10^{3} \mathrm{~m}^{3}\right]\end{array}$ & $\begin{array}{c}\text { Area of reservoir } \\
\text { [ha] }\end{array}$ & $\begin{array}{c}\text { Mean annual water flow } \\
\text { Q }\left[\mathrm{m}^{3} \cdot \mathrm{s}^{-1}\right]\end{array}$ \\
\hline \multicolumn{4}{|l|}{ Designed reservoirs } \\
\hline Piekary / Szczyrzawy & 45 & 18.0 & 0.046 \\
\hline Tonie / Sudół & 73 & 5.1 & 0.190 \\
\hline Węgrzce / Sudół Dominikański & 204 & 8.9 & 0.036 \\
\hline Janowice / Wilga & 440 & 14.3 & 0.130 \\
\hline \multicolumn{4}{|l|}{ Operated reservoirs } \\
\hline Krempna / Wisłok & 119 & 3.7 & 2.030 \\
\hline Zesławice / Dłubnia & 228 & 9.5 & 1.090 \\
\hline Maziarnia / Łęg & 3,860 & 160.0 & 1.270 \\
\hline Cierpisz / Tuszymka & 34 & 2.3 & 0.933 \\
\hline Niedźwiadek/ Górno & 125 & 8.1 & 1.666 \\
\hline Narożniki / Dęba & 283 & 28.0 & 1.555 \\
\hline
\end{tabular}

due to silting of over 43\%. The Niedźwiadek reservoir on the Górno River was built in 1988, and the Narożniki reservoir on the Dęba River was built in 2001. These reservoirs have not been desilted yet. They were built to store water for agriculture, serve as water intake by local waterworks or recreation.

The location of the four designed reservoirs was planned near Kraków, at a distance of about 7 to $15 \mathrm{~km}$ in the north, west and south directions. The Piekary and the Tonie reservoirs are to serve as flood protection. They were designed as dry reservoirs. The basic parameters of the planned reservoirs are shown in Table 1. The catchments of these reservoirs are located in the city of Kraków or in its immediate vicinity. The main aim of the construction of the planned reservoirs is the water flow regulation, both during high water levels and in drought periods, improvement of water circulation in the valleys of their watercourses and to have a limited role as flood protection for the Kraków agglomeration [35].

Arable lands occupy the largest area in the catchments of the planned reservoirs, constituting over $40 \%$, with the exception of the Tonie reservoir (Table S1). Forests occupy the largest area of the planned Tonie reservoir catchment. The catchments of the six existing reservoirs are mainly used for agricultural purposes. Their significant area is occupied by arable land, except for the catchment of the Krempna reservoir, which is in $80 \%$ occupied 
by forests, and the catchment area of the Cierpisz reservoir, which is in $43 \%$ covered with forests (Table S1).

\subsection{Sample Collection}

\subsubsection{Water sampling}

Samples of water flowing into the existing and planned reservoirs were collected in the point of sampling in the measuring cross-sections, located above the backwater range of the reservoirs, i.e. outside the range of damming effects. The cross-sections were determined, apart from the water sampling, to make a hydrometrical measurements. Based on the hydrometrical measurements of water velocity the rating curves were made. At the cross-sections also a suspended sediment load was measured. In the case of the designed reservoirs, the location of measuring cross-sections in the Szczyrzawa, Sudół, Sudół Dominikański and in the upper Wilga were designated in the cross-sections of dams of the designed reservoirs. The Szczyrzawa and Wilga streams flow directly into the Vistula, while the Sudół and Sudół Dominikański streams flow into Białucha, which is a left-hand tributary of the Vistula. Water samples were collected in 2007-2009. They were collected once per quarter in the middle of the cross-sections of streams from a depth of about $0.2 \mathrm{~m}$ below the water surface. Water samples (volume of $500 \mathrm{~mL}$ ) were collected during low flows, into chemically clean polypropylene containers. $\mathrm{HNO}_{3}$ and $30 \% \mathrm{H}_{2} \mathrm{O}_{2}$ were added to the water samples in the containers and then were transported to the laboratory. At the inflows to the existing reservoirs, water samples were collected over a period of three years. In the period of 2003-2005 water samples were collected at the inflows to the Krempna and Niedźwiadek reservoirs, in 2004-2006 at the inflow to the Zesławice reservoir and in 2001-2003 at the inflows to the Cierpisz, Maziarnia and Narożniki reservoirs [36]. Twelve water samples were collected in each of the six existing reservoirs were taken in the appointed cross-sections, at the tributaries to the reservoirs, where automatic monitoring stations have been installed. Samples of water were taken at the depth about $0.2 \mathrm{~m}$ below the water table. At these stations in a continuous way, the water stage and atmospheric precipitation (rain) was recorded. On the basis of the hydrograph and precipitation analysis, when flood was stated (Fig. S1), water samples were taken. After the flood, when water stages related to low flows, the silting-up was measured and samples of bed material was taken. Results of the silting-up are in the works $[8,34,36]$. In the Fig. S1 exemplary hydrograph of Dhubnia river (Zesławice reservoir), for the hydrological year 2001 is presented. In this hydrograph five flood waves are marked, during which samples of water were taken. The water samples were taken during the flood crest. The water samples in the containers were fixed by adding $\mathrm{HNO}_{3}$ and $30 \% \mathrm{H}_{2} \mathrm{O}_{2}$ and transported to the laboratory.

\subsubsection{Sediment sampling}

Twelve sediment samples in each of the six reservoirs were collected in cross-sections located in the near-dam, central and backwater parts of those reservoirs (Fig. S2). In each of the mentioned parts of reservoirs, samples were collected from the surface of the bottom sediments.

Collection of sediment samples was made after flood, during which samples of water in the cross-sections located at the inlet to the reservoirs were taken. The measurements were made when water stages corresponded to low flows. In case of analyzed reservoirs the siltin-up was also measured. Description of the silting processes and its results are in the works [8, 34, 36]. On the basis of these results a mean annual silting ratio $\left(\mathrm{S}_{\mathrm{A}}\right)$ for every reservoir was calculated. Silting ratio (S) is a relationship of the sediment volume to the volume of reservoir. Based on the mean annual silting ratio $\mathrm{S}_{\mathrm{A}}[\%]$ the mean annual volume of recharged sediment was calculated, and on this basis mean thickness of recharged sediment, the sediment thickness is evaluated (Table S2).

Given in the table he values of mean annual thickness of deposited sediment refer to the whole area of each reservoir. The thickness of the deposited sediment during a year at the inlet to the reservoir was even 3-4 times higher to the $h_{A}$ (Table S2). It means that after every water sampling at the inlet to reservoir, the samples from drift, either from newly deposited sediment layer was taken. During the measurement the sediment from the bottom sediment surface (i.e. at the depth 0-15 cm - upper layer) and at the depth 40-55 cm under sediment surface (lower part) [36] was taken. The studies covered the surface layer of the sediments $(0-0.5 \mathrm{~cm})$, because its chemical composition reflects the sedimentation and remobilization processes occurring shortly after the retention of sediments in the reservoir [37]. The properties of the sediments from this layer undergo significant changes throughout the year, due to intense physicochemical and biological processes occurring therein. Separation of this layer was dictated by the need to eliminate the effect of the concentration of the investigated metals, deposited in the deeper layers of the sediment in the period before the water and sediment sampling campaigns. The samples of sediments were collected by a $5 \mathrm{~cm}$-diameter polyethylene pipe sampler. The surface layer $(0-0.5 \mathrm{~cm})$ was separated from the collected core samples. All sediment samples, after the decantation of overlying water, were refrigerated until analyzes.

\subsection{Chemical Analyzes}

The collected water samples, after prior mineralization, were subjected to heavy metal concentration determination by atomic absorption spectrophotometry on a UNICAM SOLAR 969 spectrometer. The $\mathrm{pH}$ was determined in situ with the CX-742 Elmetron apparatus.

Before heavy metal analyzes, the sediment samples were dried at $105^{\circ} \mathrm{C}$ for 48 hours. The sediment samples were mineralized in concentrated $\mathrm{HNO}_{3}$ in the mineralizer. Heavy metal concentrations determined in the obtained solutions were referred to as "total". The total concentration of heavy metals was determined after subjecting the samples to the two-stage pressure microwave mineralization, followed by an ICP-AES spectroscopic analysis. The accuracy of the analyzes was checked using certified BCR-701 reference material by blank analysis. Samples were analyzed in duplicate to eliminate any batch-specific error. The results showed that the percentage of recovery ranged from 89 to $112 \%$ for $\mathrm{Pb}$, from 91 to $118 \%$ for $\mathrm{Cd}$, and from 85 to $115 \%$ for Ni.

The grain size distribution of the sediment samples and the content of organic matter carbon were also determined. The aerometric method was used to analyze the grain size fractions. The organic matter carbon (COM) content was determined by loss-on-ignition for 8 hours at $450^{\circ} \mathrm{C}$. The $\mathrm{pH}$ was measured at a 1:2.5 sediment: 
liquid ratio with $1 \mathrm{~mol} \mathrm{KCl} \mathrm{dm}{ }^{-3}$ [38].

\subsubsection{Assessment of heavy metal pollution}

The lead, cadmium and nickel pollution was assessed for water flowing into the planned reservoirs. An assessment of the forecast pollution of sediments of these water reservoirs was also made with reference to the permissible levels of environmental concentrations according to various criteria, including Polish ones [39]. The contamination of water flowing into the planned reservoirs was assessed according to the Water Quality Criteria taking into account drinking water quality and protection of aquatic life (Table S3).

The forecast metal concentration in the sediments of the planned reservoirs was compared with the values given by MacDonald [40, 41]. These values were grouped, by distinguishing threshold (TEL, ERL, LEL and MEL), midrange (PEL and ERM) and extreme (TEL and SEL) effect levels according to [21] sediment quality guidelines (Table S4). The most widely used SQGs are the empirically based approaches (ERL-ERM, TEL-PEL) on a site-specific basis [21]. These approaches generally set two threshold levels, one below which effects rarely occur - e.g., the lowest effect level (LEL), threshold effect level (TEL), effects range low (ERL), minimal effect threshold (MET), and threshold effect concentration (TEC), and one above which effects are likely to occur - e.g., the severe effect level (SEL), probable effects level (PEL), effect range median (ERM), toxic effect threshold (TET) [21]. ERL (effect low range) and TEL (threshold effect level) represent concentrations below which a toxic effect on aquatic organisms will rarely occur, while ERM (effect medium range) and PEL (probable effect level) refer to concentration levels above which adverse effects are likely to occur [42]. The concentrations in between ERL and ERM and TEL and PEL, represent values within which adverse effects will likely occur [42].

Geoaccumulation index ( $\left.\mathrm{I}_{\text {geo }}\right)$ according to Müller [43] was also determined:

$$
\mathrm{I}_{\mathrm{geo}}=\log _{2} \mathrm{C}_{\mathrm{n}} / 1,5 \cdot \mathrm{B}_{\mathrm{n}}
$$

where: $C_{n}$ - the content of the element in the sediment, $B_{n}$ - value of the geochemical background of the element in shales $(\mathrm{Pb} 20$ $\mu \mathrm{g} \cdot \mathrm{g}^{-1}$, Cd $0,3 \mu \mathrm{g} \cdot \mathrm{g}^{-1}$, Ni $68 \mu \mathrm{g} \cdot \mathrm{g}^{-1}$ ) [44].

Based on the $\mathrm{I}_{\text {geo }}$ value, [43] determined 7 classes of sediment purity, from completely unpolluted (class 0 ) to extremely polluted (class 6).

\subsubsection{Elaboration of research results}

The minimum and maximum values of $\mathrm{Pb}, \mathrm{Cd}$ and $\mathrm{Ni}$ concentrations in the water of inflows to the designed reservoirs were determined using the empirical database, and arithmetic means, medians and standard deviations were calculated. Based on the coefficients of variation calculated from the ratio of standard deviation and the mean value, the variability of data in the sets was assessed - four variation classes were used: small diversity (0-20\%), medium diversity (21-40\%), large diversity (41-60\%) and very large diversity (> 60\%). The cross-object significance of differences in the mean values of the tested metal concentrations in water of inflows to the planned reservoirs was estimated by the Student's t-test [45] at a significance level of 0.05 . The results of these statistical analyzes are presented in the study of Kanownik et al. [17]. The results of these statistical analyzes are presented in the study of Kanownik et al. [17]. The significance of differences in the mean values of the analyzed metal concentrations in water and sediments of existing reservoirs was determined by the analysis of variance (ANOVA) at a significance level of 0.05 .

The results of determination of $\mathrm{Pb}, \mathrm{Cd}$ and $\mathrm{Ni}$ concentrations in the water flowing into the planned reservoirs were used to estimate the total concentration of these metals in the sediments that will be accumulated in these reservoirs after their construction. For this purpose, based on the results of heavy metal concentration tests in the sediment of the six reservoirs tested and the water flowing therein, a correlation dependence of the concentration of a given metal in the sediment on the concentration of this metal in the water flowing into the reservoir will be developed. These relationships were evaluated using Pearson's correlation coefficient. All statistical analyzes were performed using Microsoft Excel and STATISTICA 12.0 software.

\section{Results}

\subsection{Assessment of Water Pollution of Inflows to the Planned Reservoirs}

The lowest maximum values of cadmium and nickel concentration in water of inflows to the planned reservoirs were found in the Szczyrzawa and Wilga watercourses (Table 2). The concentrations of these metals proved to be lower than the maximum values, found in waters of the Sudół Dominikański stream by about $68 \%$ and more than nine times, for the concentrations of cadmium and nickel, respectively. The lowest of the maximum values of lead concentrations occurred in the waters of the Sudół and Sudół Dominikański streams and proved to be more than three times lower than the maximum concentrations of this metal in the Szczyrzawa and Wilga streams. The maximum values oscillated generally around hundredth, while mean values around thousandth parts of milligram per $1 \mathrm{dm}^{-3}$. In some of the collected water samples, the tested metals were not detected, hence in Table 4 zero values in the column with the minimum values of those indicators. Coefficients of variation ranged from 50 to $300 \%$ (Table 2), so the concentrations of the heavy metals tested were characterized by large and very large statistical diversity. The analysis carried out by the parametric Student's test did not show any significant differences between the waters of the examined streams in terms of mean concentrations of the three trace elements determined [17].

With respect to the maximum concentration of lead, it can be stated that the waters of the Szczyrzawa and Wilga streams exceed practically all the drinking water quality criteria (Table S3). The waters of all four streams do not meet the US EPA criterion [46] that does not allow any concentration of lead in the water. The waters of the Szczyrzawa and Wilga streams also exceed the criterion of protection of aquatic life according to [46].

Considering the maximum cadmium concentrations, it was found that the waters of all streams meet the majority of drinking water quality criteria listed in Table 2, with the exception of two with very low limit values of $0.00045 \mathrm{mg} \cdot \mathrm{dm}^{-3}$. These are the Polish 
Table 2. Descriptive Statistics of the Heavy Metal Concentrations in Water - Designed Reservoirs [17]

\begin{tabular}{|c|c|c|c|c|c|c|c|}
\hline \multirow{2}{*}{ Heavy metal } & \multirow{2}{*}{ Water-course } & \multicolumn{4}{|c|}{ Content of heavy metals in water $\left[\mathrm{mg} \cdot \mathrm{dm}^{-3}\right]$} & \multirow{2}{*}{ SD $^{*}$} & \multirow{2}{*}{$\mathrm{CV}^{*}[\%$} \\
\hline & & $\min$. & $\max$ & mean & median & & \\
\hline \multirow{4}{*}{$\mathrm{Pb}$} & Szczyrzawy & 0 & 0.019 & 0.005 & 0.002 & 0.006 & 120 \\
\hline & Sudół & 0 & 0.006 & 0.003 & 0.003 & 0.002 & 67 \\
\hline & Sudół Dominikański & 0 & 0.006 & 0.003 & 0.003 & 0.002 & 67 \\
\hline & Wilga & 0.001 & 0.019 & 0.006 & 0.002 & 0.007 & 117 \\
\hline \multirow{4}{*}{$\mathrm{Cd}$} & Szczyrzawy & 0 & 0.0012 & 0.0001 & 0 & 0.0003 & 300 \\
\hline & Sudół & 0 & 0.002 & 0.0003 & 0 & 0.0006 & 200 \\
\hline & Sudół Dominikański & 0 & 0.002 & 0.0003 & 0 & 0.0008 & 267 \\
\hline & Wilga & 0 & 0.0015 & 0.0002 & 0 & 0.0005 & 250 \\
\hline \multirow{4}{*}{$\mathrm{Ni}$} & Szczyrzawy & 0.002 & 0.008 & 0.0038 & 0.004 & 0.002 & 50 \\
\hline & Sudół & 0.001 & 0.015 & 0.005 & 0.004 & 0.004 & 80 \\
\hline & Sudół Dominikański & 0 & 0.073 & 0.009 & 0.004 & 0.02 & 222 \\
\hline & Wilga & 0.001 & 0.008 & 0.0035 & 0.003 & 0.002 & 50 \\
\hline
\end{tabular}

* SD - standard deviation, CV - coefficient of variation

criteria of [39] and the European Parliament [47]. Unfortunately, waters of all streams do not meet the criterion of protection of aquatic life according to US EPA [46].

In the case of maximum nickel concentrations, only water of the Sudół Dominikański stream do not meet all the drinking water quality criteria (Table S3). The US EPA criterion [46] was also exceeded by the maximum nickel concentration in the water of the Sudół stream. Also, waters of neither of these two streams meet the criterion of protection of aquatic life according to [46].

The threshold values given for drinking water quality (Table S3) were not exceeded by the mean concentrations of the heavy metals tested in the waters of four streams: Szczyrzawy, Sudół, Sudół Dominikański and Wilga. Therefore, it can be concluded that there is no dangerous lead, cadmium and nickel pollution of these streams. The $\mathrm{pH}$ of water determined in streams of the designed reservoirs (Table S5) ranged from 7.0 to 8.6. The $\mathrm{pH}$ of water was characterized by small diversity, both between and within individual watercourses (CV of 2-3\%).

\subsection{Assessment of Water and Sediment Pollution of the Existing Reservoirs}

Table 3 shows the minimum, mean and maximum concentrations of lead, cadmium and nickel in sediments and water flowing into the six operated small reservoirs.qkr

The basic physicochemical properties of sediments collected from the bottom of the six exploited reservoirs are given in Table 4. The $\mathrm{pH}$ of sediments was slightly acidic and ranged from 6.0 to 6.9 in reservoirs Zesławice and Maziarnia. The sediment of the Niedźwiadek reservoir was characterized by the most acidic $\mathrm{pH}$ as compared to the other five reservoirs. The $\mathrm{pH}$ values of the Niedżwiadek reservoir sediment samples are in the range from 5.1 to 5.7. Sediments of the Krempna, Cierpisz and Narożniki reservoirs are alkaline. In the examined reservoirs, the sediment's $\mathrm{pH}$ decreases with increasing depth. In the samples No. III (Table 4), collected near the dams of the Krepmpna, Zesławice, Cierpisz and Niedźwiadek reservoirs, the recorded $\mathrm{pH}$ values were the lowest compared to the samples collected in the central (II) and inlet (I) parts of these reservoirs.

The content of organic matter in the sediments of the examined reservoirs was from 3.2 to $6.9 \%$ (Table 4 ). The highest organic matter content was found mainly in the sediments collected from the inlet parts of the reservoirs (samples No. I).

\subsection{Development of Correlation Dependence of Metal Concentration in Water and Sediment}

Twelve water and sediment samples were collected in each of the six existing reservoirs, i.e. four samples per each of the three years of the experiment [36]. The analyzes conducted on the samples collected from the six reservoirs provided data series regarding the concentration of a particular metal in water and in the sediment. Coefficients of variation (CV) calculated for twelve-element data series, including concentrations of a given metal in a sample of water and sediment of the six operated reservoirs, are usually smaller than $60 \%$ (Table 3), indicating small, medium or large statistical diversity. The exception is in the case of the cadmium concentrations in the sediments of the Cierpisz reservoir, cadmium in the water flowing to the Zesławice and Maziarnia reservoirs, as well as lead and cadmium in the water supplying the Cierpisz reservoir (Table 3 ) - variation coefficient values above $60 \%$ indicate a very large variation in the data sets of the metal concentrations. The determined relationships between the concentrations of the examined heavy metals in water and in the sediments of the six operated reservoirs are presented in Fig. 2. For all the tested heavy metals there was a strong positive correlation - the Pearson R correlation coefficient in the range of 0.54-0.83 ( $\mathrm{R}>0.5$ means a strong correlation [45]). On the other hand, the values of the determination coefficient $\mathrm{R}^{2}$, indicating the percentage of the dependent variable explained by means of an independent variable, in the case of lead and nickel were 0.62 and 0,69 , respectively, which indicates 
Table 3. Content of Heavy Metals (Pb, Cd and $\mathrm{Ni}$ ) in Water and in Sediments Deposited in Small Reservoirs at Krempna, Zesławice, Maziarnia, Cierpisz, Niedźwiadek and Narożniki

\begin{tabular}{|c|c|c|c|c|c|c|c|}
\hline \multirow{2}{*}{ Reservoir } & \multirow{2}{*}{ Value } & \multicolumn{3}{|c|}{ Heavy metals in water $\left[\mathrm{mg} \cdot \mathrm{dm}^{-3}\right]$} & \multicolumn{3}{|c|}{ Heavy metals in sediments $\left[\mathrm{mg} \cdot \mathrm{kg}^{-1}\right]$} \\
\hline & & $\mathbf{P b}$ & Cd & $\mathrm{Ni}$ & $\mathbf{P b}$ & Cd & $\mathrm{Ni}$ \\
\hline \multirow{5}{*}{ Krempna } & Min. & 0.0012 & 0.00001 & 0.0095 & 9.8 & 0.1 & 42.3 \\
\hline & Mean & 0.0024 & 0.00003 & 0.0123 & 17.5 & 0.3 & 52.9 \\
\hline & Max. & 0.0031 & 0.00005 & 0.0141 & 21.0 & 0.5 & 66.1 \\
\hline & $\mathrm{SD}^{*}$ & 0.00059 & 0.00001 & 0.00178 & 3.98 & 0.16 & 7.05 \\
\hline & $\mathrm{CV}^{*}[\%]$ & 25 & 33 & 14 & 23 & 53 & 13 \\
\hline \multirow{5}{*}{ Zesławice } & Min. & 0.0018 & 0.00001 & 0.0068 & 10.5 & 0.1 & 14.7 \\
\hline & Mean & 0.0031 & 0.00004 & 0.0089 & 20.0 & 0.5 & 16.2 \\
\hline & Max. & 0.0049 & 0.00009 & 0.0106 & 30.2 & 0.9 & 17.5 \\
\hline & $\mathrm{SD}^{*}$ & 0.00125 & 0.00003 & 0.00118 & 6.88 & 0.29 & 1.06 \\
\hline & $\mathrm{CV}^{*}[\%]$ & 40 & 75 & 13 & 34 & 58 & 7 \\
\hline \multirow{5}{*}{ Maziarnia } & Min. & 0.0011 & 0.00001 & 0.0022 & 8.7 & 0.1 & 8.4 \\
\hline & Mean & 0.0015 & 0.00003 & 0.0037 & 9.5 & 0.3 & 9.3 \\
\hline & Max. & 0.0019 & 0.00005 & 0.0061 & 11.5 & 0.5 & 11.2 \\
\hline & $\mathrm{SD}^{*}$ & 0.00029 & 0.00002 & 0.00121 & 0.93 & 0.14 & 1.05 \\
\hline & $\mathrm{CV}^{*}[\%]$ & 19 & 67 & 33 & 10 & 47 & 11 \\
\hline \multirow{5}{*}{ Cierpisz } & Min. & 0.0001 & 0.00001 & 0.0013 & 1.0 & 0.1 & 5.1 \\
\hline & Mean & 0.0006 & 0.00003 & 0.0021 & 5.4 & 0.9 & 7.4 \\
\hline & Max. & 0.0014 & 0.00005 & 0.0028 & 10.5 & 2.8 & 12.6 \\
\hline & $\mathrm{SD}^{*}$ & 0.00045 & 0.00002 & 0.00055 & 2.68 & 0.80 & 2.34 \\
\hline & $\mathrm{CV}^{*}[\%]$ & 75 & 67 & 26 & 50 & 89 & 32 \\
\hline \multirow{5}{*}{ Niedźwiadek } & Min. & 0.0013 & 0.00002 & 0.0063 & 11.1 & 0.5 & 19.2 \\
\hline & Mean & 0.005 & 0.00004 & 0.0087 & 23.8 & 1.3 & 23.7 \\
\hline & Max. & 0.0061 & 0.00008 & 0.0112 & 34.3 & 1.9 & 25.4 \\
\hline & $\mathrm{SD}^{*}$ & 0.00161 & 0.00002 & 0.00177 & 6.77 & 0.63 & 2.12 \\
\hline & $\mathrm{CV}^{*}[\%]$ & 32 & 50 & 20 & 28 & 48 & 9 \\
\hline \multirow{5}{*}{ Narożniki } & Min. & 0.0009 & 0.00003 & 0.0059 & 8.3 & 0.6 & 19.1 \\
\hline & Mean & 0.0019 & 0.00006 & 0.0078 & 12.4 & 0.8 & 23.4 \\
\hline & Max. & 0.0024 & 0.00007 & 0.0093 & 15.2 & 1.2 & 29.6 \\
\hline & $\mathrm{SD}^{*}$ & 0.00044 & 0.00002 & 0.00093 & 2.46 & 0.21 & 3.14 \\
\hline & $\mathrm{CV}^{*}[\%]$ & 23 & 33 & 12 & 20 & 26 & 13 \\
\hline
\end{tabular}

${ }^{*} \mathrm{SD}$ - standard deviation, CV - coefficient of variation

Table 4. Main Physicochemical Characteristics of the Sediments of the Operated Reservoirs

\begin{tabular}{|c|c|c|c|c|c|c|c|}
\hline \multirow{2}{*}{ Reservoir } & \multirow{2}{*}{ No. of sampling point } & \multicolumn{3}{|c|}{ Granulometric (\%) } & \multicolumn{2}{|c|}{ Organic matter } & \multirow{2}{*}{$\begin{array}{l}\text { pH } \\
\text { KCl }\end{array}$} \\
\hline & & Sand & Silt & Clay & $(\%)$ & SD & \\
\hline \multirow{3}{*}{ Krempna } & I & 17 & 71 & 12 & 4.1 & 1.1 & $7.7-7.9$ \\
\hline & II & 56 & 33 & 11 & 3.7 & 0.5 & $7.3-7.5$ \\
\hline & III & 71 & 22 & 7 & 4.0 & 0.7 & 7.4-7.7 \\
\hline \multirow{3}{*}{ Zesławice } & I & 4 & 85 & 11 & 3.2 & 1.0 & $6.2-6.4$ \\
\hline & II & 13 & 76 & 11 & 3.2 & 0.8 & $6.5-6.6$ \\
\hline & III & 19 & 80 & 1 & 4.4 & 0.6 & $6.1-6.4$ \\
\hline \multirow{3}{*}{ Maziarnia } & I & 61 & 28 & 11 & 4.1 & 1.11 & $6.0-6.4$ \\
\hline & II & 69 & 21 & 10 & 4.6 & 1.9 & $6.1-6.2$ \\
\hline & III & 69 & 23 & 8 & 5.3 & 1.2 & $6.0-6.2$ \\
\hline \multirow{3}{*}{ Cierpisz } & I & 15 & 76 & 9 & 3.4 & 2.0 & $7.7-7.9$ \\
\hline & II & 22 & 74 & 4 & 3.3 & 1.7 & 7.6-7.8 \\
\hline & III & 21 & 61 & 18 & 4.2 & 0.8 & $7.5-7.8$ \\
\hline \multirow{3}{*}{ Niedźwiadek } & I & 9 & 79 & 12 & 4.3 & 1.5 & $5.4-5.7$ \\
\hline & II & 12 & 77 & 11 & 4.3 & 1.7 & $5.3-5.5$ \\
\hline & III & 20 & 65 & 15 & 5.5 & 1.0 & $5.1-5.4$ \\
\hline \multirow{3}{*}{ Narożniki } & I & 5 & 86 & 9 & 4.8 & 0.9 & $7.6-7.8$ \\
\hline & II & 10 & 86 & 4 & 6.9 & 1.6 & 7.4-7.6 \\
\hline & III & 16 & 76 & 8 & 6.8 & 1.3 & 7.6-7.7 \\
\hline
\end{tabular}



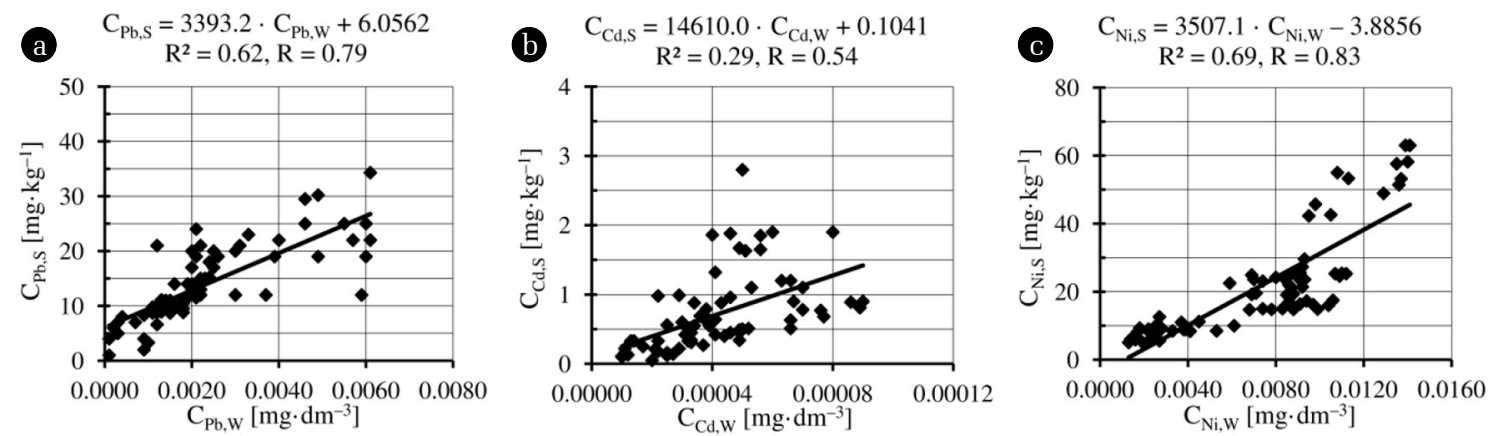

Fig. 2. Relationship between the concentration of lead (a), cadmium (b) and nickel (c) in water and sediment of the reservoirs Krempna, Zesławice, Maziarnia, Cierpisz, Niedźwiadek and Narożniki: $C_{S}$ - concentration of heavy metals in the sediment; $C_{W}-$ concentration of heavy metals in water.

a satisfactory fit of the linear model. The value $\mathrm{R}^{2}=0.29$ for the relationship of cadmium concentration in water and bottom sediments, indicates an unsatisfactory fit of the statistical model to empirical data. For these reasons, the predicted concentrations of lead and nickel in the bottom sediments of the designed reservoirs should be considered very likely, while for cadmium these values should be considered as highly estimated.

\subsection{Forecast of Lead, Cadmium and Nickel Concentration in the Sediments of the Designed Small Reservoirs}

The estimated heavy metal contamination of the sediments of the designed reservoirs in the Kraków agglomeration area was calculated based on the established correlation relationships shown in Fig. 2. The forecast concentration of lead, cadmium and nickel in the sediments (Table 5), that will accumulate in the designed reservoirs, was determined for the maximum and mean concentrations of particular metal in water (Table S3).

\subsection{Forecast of the Degree of Sediment Contamination of the Planned Reservoirs}

The assessment of lead, cadmium and nickel contamination of the planned reservoirs was developed on the basis of the forecast mean concentration of these elements in bottom sediments (Table 5). According to the threshold effect sediment quality guidelines for metals, the forecast mean concentrations of lead will not exceed the values of TEL, ERL, LEL and MET. The forecast maximum lead concentrations in the sediments were exceeded in the case of only two reservoirs, i.e. Piekary and Janowice. The forecast maximum and mean concentrations of this metal do not exceed the value of the midrange effect sediment quality guidelines for metals and extreme effect sediment quality guidelines for metals (Table S4).

The relationship presented in Fig. 2, due to the unsatisfactory measure of data fit, i.e. the value of determination coefficient $\mathrm{R}^{2}$ less than 0.5, was adopted for the preliminary estimation of cadmium contamination of sediments of the designed reservoirs. The estimated mean cadmium concentrations will not exceed the effects range low (ERL) threshold value, as well as the ERM and SEL values. These concentrations exceed the remaining threshold values (Table S4), except for the PEL and TET values in the case of two reservoirs, i.e. Piekary and Janowice. It has been estimated that none of the limit values (Table S4) will be exceeded by the maximum cadmium concentrations in the sediments of the planned reservoirs.

Table 5. Forecast Concentrations of Lead, Cadmium and Nickel in Sediments of the Designed Reservoirs in the Region of the Kraków Agglomeration

\begin{tabular}{|c|c|c|c|}
\hline \multirow{2}{*}{ Heavy metal } & \multirow{2}{*}{ Water-course } & \multicolumn{2}{|c|}{ Concentration of heavy metals in sediment $\left[\mathrm{mg} \cdot \mathrm{kg}^{-1}\right]$} \\
\hline & & max. & mean \\
\hline \multirow{4}{*}{$\mathrm{Pb}$} & Piekary / Szczyrzawy & 70.5 & 23.0 \\
\hline & Tonie / Sudoł & 26.4 & 16.2 \\
\hline & Węgrzce / Sudoł Dominikański & 26.4 & 16.2 \\
\hline & Janowice / Wilga & 70.5 & 26.4 \\
\hline \multirow{4}{*}{$\mathrm{Cd}$} & Piekary / Szczyrzawy & 17.6 & 1.6 \\
\hline & Tonie / Sudoł & 29.3 & 4.5 \\
\hline & Węgrzce / Sudoł Dominikański & 29.3 & 4.5 \\
\hline & Janowice / Wilga & 22.0 & 3.0 \\
\hline \multirow{4}{*}{$\mathrm{Ni}$} & Piekary / Szczyrzawy & 24.2 & 9.4 \\
\hline & Tonie / Sudoł & 48.7 & 13.6 \\
\hline & Węgrzce / Sudoł Dominikański & 252.1 & 27.7 \\
\hline & Janowice / Wilga & 24.2 & 8.4 \\
\hline
\end{tabular}


Table 6. Geoaccumulation Index (Igeo) According to Müller [43] and Class of Pollution for Determining the Quality of Sediment and Exceeded EQS Criterion for Sediments of the Designed Reservoirs in the Region of the Kraków Agglomeration

\begin{tabular}{|c|c|c|c|c|c|c|c|}
\hline \multirow{2}{*}{ Heavy metal } & \multirow{2}{*}{ Water-course } & \multicolumn{2}{|c|}{$\mathbf{I}_{\text {geo }}$} & \multicolumn{2}{|c|}{ Class of pollution } & \multicolumn{2}{|c|}{ Exceeded EQS criterion } \\
\hline & & $\max$. & mean & $\max$. & mean & $\max$. & mean \\
\hline \multirow{4}{*}{$\mathrm{Pb}$} & Piekary / Szczyrzawy & 1,65 & 0,03 & 2 & 1 & MET & - \\
\hline & Tonie / Sudoł & 0,23 & $-0,47$ & 1 & 0 & - & - \\
\hline & Węgrzce / Sudoł Dominikański & 0,23 & $-0,47$ & 1 & 0 & - & - \\
\hline & Janowice / Wilga & 1,65 & 0,23 & 2 & 1 & MET & - \\
\hline \multirow{4}{*}{$\mathrm{Cd}$} & Piekary / Szczyrzawy & 3,45 & 1,06 & 4 & 2 & SEL & TEL \\
\hline & Tonie / Sudoł & 5,29 & 2,58 & 5 & 3 & SEL & TEL \\
\hline & Węgrzce / Sudoł Dominikański & 5,39 & 2,58 & 5 & 3 & SEL & TEL \\
\hline & Janowice / Wilga & 4,88 & 2,01 & 4 & 3 & SEL & TEL \\
\hline \multirow{4}{*}{$\mathrm{Ni}$} & Piekary / Szczyrzawy & 1,69 & 0,33 & 2 & 1 & TEL & - \\
\hline & Tonie / Sudoł & 2,70 & 0,86 & 3 & 1 & PEL & - \\
\hline & Węgrzce / Sudoł Dominikański & 5,07 & 1,88 & 5 & 2 & SEL & TEL \\
\hline & Janowice / Wilga & 1,69 & 0,16 & 2 & 1 & TEL & - \\
\hline
\end{tabular}

Where quality of sediment for class: 0 - unpolluted, 1 - unpolluted to moderately polluted, 2 - moderately polluted, 3 - moderately to strongly polluted, 4 - strongly polluted, 5 - strongly to extremely polluted, 5 - extremely polluted

The forecast mean nickel concentrations do not exceed the threshold values for the criteria of midrange effect sediment quality guidelines for metals (i.e. values for PEL and ERM) and extreme effect sediment quality guidelines for metals (i.e. values for TET and SEL). None of the effect sediment quality guidelines for metals threshold values will be exceeded by the forecast mean cadmium concentrations, except the Węgrzce reservoir, for which all cadmium concentration limits are exceeded (apart from the ERL limit).

Table 6 presents the expected values of the geoaccumulation index ( $\mathrm{I}_{\text {geo }}$ ) [43]. It was calculated for the projected mean concentration of lead, cadmium and nickel (Table 5). According to the criteria of this classification, the calculated values of the geoaccumulation index due to the content of lead allow to consider the sediments accumulated in the designed reservoirs as practically unpolluted or moderately polluted. However, due to the content of cadmium and nickel, this sediment can be moderately or even heavily polluted (Table 6).

\section{Discussion}

Numerous studies conducted so far, prove that the waters flowing out of the catchments in settlement and suburban areas, especially in watercourses flowing through urban areas, are characterized by poorer quality indicators compared to those in agricultural areas [23, 48-53]. This is confirmed in our study by the mean and maximum concentrations of lead, cadmium and nickel determined in water of the watercourses on which the reservoirs of the Kraków agglomeration are designed. These concentrations are higher than the mean and maximum concentrations of these metals in waters flowing into the operated reservoirs located in agricultural catchments. And so, the mean concentrations of lead are from $20 \%$ to five times higher, mean concentrations of cadmium - from 33 to 55 times higher, while mean concentrations of nickel are from 1.4 to 3 times higher than the previously mentioned concentrations. The impact of the catchment use on the content of heavy metals in sediments of reservoirs is confirmed by the results of research by many authors [24, 54, 55]. Sojka et al. [24] found, based on research on heavy metals in reservoirs located in the lowland area of western Poland, that heavy metal concentrations in bottom sediments are lower in the analyzed reservoirs located in agricultural catchment. According to Baran and Tarnawski [56] sediment contaminated with heavy metals is generally an effect of intensive human impact on the area where reservoirs are located. The results of the determination of heavy metals in six operated reservoirs presented in this paper proved to be lower than those determined by Salata et al. [57] in sediments of eight small reservoirs located in agricultural catchments in south eastern Poland. Salata et al. [57] report that the mean concentration of lead in water reservoirs ranged from 20.9 to $39.9 \mathrm{mg} \cdot \mathrm{kg}^{-1}$.

However, in the reservoirs examined in this study mean concentration of lead was lower and ranged from 9.5 to $20.5 \mathrm{mg} \cdot \mathrm{kg}^{-1}$, and the forecasted mean concentration of this metal in four planned reservoirs ranged from 16.2 to $26.4 \mathrm{mg} \cdot \mathrm{kg}^{-1}$. Also, mean concentration of cadmium proved to be higher in the reservoirs studied by Salata et al. [57], because the highest mean concentration of cadmium was $17.5 \mathrm{mg} \cdot \mathrm{kg}^{-1}$, and in the studied six reservoirs it was only $1.3 \mathrm{mg} \cdot \mathrm{kg}^{-1}$. The projected mean concentration of this metal in four planned reservoirs ranged from 1.6 to $4.5 \mathrm{mg} \cdot \mathrm{kg}^{-1}$. In the study of Salata et al. [57], no nickel concentration was given.

The assessment of heavy metal content in the sediments of the six analyzed reservoirs was presented in the studies [34, 58, 59]. According to the general assessment presented in these papers, the sediments of the examined small reservoirs of southern Poland do not show significant heavy metal pollution. With respect to individual classifications of heavy metal pollution, the sediments of small reservoirs can be considered as posing no environmental threat. However, the results of research by Salata et al. [57] indicate that in the majority of cases, the geo-accumulation indices classify the sediments as moderately or strongly polluted. 
Sediments of these reservoirs are fine-fraction mineral material, characterized by a dominant portion of silty and clay fractions. According to Baran and Tarnawski [56], small fractions, mainly silt, but also sand contained in the sediment, significantly affect the distribution of metals among different geochemical fractions. These Authors also indicate that numerous studies have shown that content of clay fraction and organic matter is the chief measure of the capacity of bottom sediments to accumulate contaminants. Research carried out by Szarek-Gwiazda [37] shows that in the Carpathian reservoirs, and these include the six reservoirs analyzed in this study, $\mathrm{pH}$ and redox conditions of the environment significantly affect the total concentration of heavy metals, while to a small extent - the forms of their occurrence in sediments. Sediments from the examined Krempna, Cierpisz and Narożniki reservoirs are characterized by alkaline $\mathrm{pH}$. Hence, the mobility of $\mathrm{Pb}, \mathrm{Cd}$ and Ni should be low, because - according to, among others [60,61] - the sediment $\mathrm{pH}$ is positively correlated with the content of $\mathrm{Pb}, \mathrm{Cd}, \mathrm{Ni}$, and also with $\mathrm{Cr}$, $\mathrm{Cu}$ and $\mathrm{Hg}$, which is associated with the low mobility of these elements in the alkaline environment. Some authors consider changes in water $\mathrm{pH}$ as one of the most important factors affecting the mobility of heavy metals in aquatic ecosystems [62-65].

The predicted concentrations of heavy metals in sediments accumulated in the planned reservoirs indicate that sediments of these reservoirs in terms of the values of mean lead and nickel concentrations (Table 5) will be unpolluted or from unpolluted to moderately polluted according to the Müller criterion [43]. Only in one of the designed reservoirs, i.e. in the Węgrzce reservoir on the Sudoł stream, the sediment will be classified as moderately polluted due to the mean concentration of nickel. This evaluation corresponds to the assessment of the sediment in this reservoir, according to EQS [40, 41]. The mean concentration of nickel in the sediment of the Węgrzce reservoir will exceed the TEL value (Table 5), which means that the mean concentration of nickel in the sediment of this reservoir will exceed the level of toxic effects on aquatic organisms. The TEL threshold value (Table 5) will be exceeded by the mean concentrations of cadmium accumulated in the sediment of each planned reservoir. This is also reflected in the results of the assessment of the sediment by means of the geoaccumulation index, since the sediment will be moderately polluted and moderately to strongly polluted due to mean cadmium concentrations in these reservoirs. However, given the maximum cadmium concentrations, the geoaccumulation index of the sediment in the designed reservoirs may be strongly polluted and strongly to extremely polluted (Table 5). Also, an exceeded SEL value indicates strong sediment contamination that is expected to be detrimental to the majority of sediment-dwelling organisms. The predicted maximum lead concentrations indicate that sediment that will be accumulated in the designed reservoirs may prove to be unpolluted to moderately polluted and moderately polluted. This sediment, defined as moderately polluted, due to the maximum concentration of lead, also exceeds a MET threshold value, i.e. the level of concentration in the environment that affects the organisms that are the most sensitive to toxic effect of a given chemical contaminant. Due to the predicted maximum concentration of nickel in the sediment, which will be accumulated in the designed reservoirs, this sediment will be moderately polluted and even strongly to extremely polluted accord- ing to EQS. The maximum nickel concentrations will exceed TEL to SEL values (Table 5). Similar results, indicating significant contamination of sediments, were reported by Kulbat and Sokołowska [64] referring to threshold values: Threshold Effect Concentration (TEC) above which the toxic effects on organisms can be observed (rarely) and Probable Effect Concentration (PEC) above which adverse biological effects often occur. The results obtained by Kulbat and Sokołowska [64] show that the PEC value was exceeded only in the case of $\mathrm{Cr}$ (75\% samples); $\mathrm{Pb}, \mathrm{Ni}$, and $\mathrm{Cd}$ were between TEC and PEC for $9.4 \%, 21.9 \%$, and $28.1 \%$ of the samples, respectively.

\section{Conclusions}

The lowest maximum values of cadmium and nickel concentration in water of inflows to the planned reservoirs were found in the Szczyrzawa and Wilga watercourses. The lowest of the maximum values of lead concentrations occurred in the waters of the Sudót and Sudół Dominikański streams. The maximum values oscillated generally around hundredth, while mean values - around thousandth parts of milligram per $1 \mathrm{dm}^{-3}$. Unfortunately, waters of all streams located in the urban agglomeration of Kraków do not meet the criterion of aquatic life protection according to US EPA [46]. In the case of the maximum nickel concentrations, water of the Sudół Dominikański stream and the Sudół stream do not meet the drinking water quality criteria. Taking into account the mean concentration of the analyzed heavy metals in the waters of investigated reservoirs it can be concluded that there is no dangerous lead, cadmium and nickel pollution of these streams. Significantly lower concentrations of lead, cadmium and nickel in waters flowing into the existing reservoirs located in non-urbanized catchment areas shall not exceed the maximum permissible concentrations. The water of these reservoirs meet both drinking water quality and protection of aquatic life threshold values.

Based on the forecast concentration of lead, cadmium and nickel in the sediments of the designed reservoirs, it can be concluded that the contamination of the sediments with these metals is higher in the reservoirs of the Kraków agglomeration than in the reservoirs located in agricultural catchments. The mean lead, cadmium and nickel concentration in the sediments of the six operated reservoirs, determined based on the data presented in Table 5, is 14.2, 0.70 and $22.1 \mathrm{mgkg}^{-1}$, respectively. The highest concentrations of lead were found in the sediments of the Niedźwiadek reservoir (34.3 mgkg $\left.{ }^{-1}\right)$. The highest concentrations of cadmium $\left(0.9 \mathrm{mgkg}^{-1}\right)$ were found in the sediments of the reservoir in Zesławice, located closest to the Krakow agglomeration. However, the highest concentrations of nickel are found in the sediments of the Krempna reservoir $\left(66.1 \mathrm{mgkg}^{-1}\right)$. Mean concentrations of these metals in the planned reservoirs are $20.5 \mathrm{mgkg}^{-1}$ for lead, $3.4 \mathrm{mg} \mathrm{kg}^{-1}$ for cadmium and $14.8 \mathrm{mgkg}^{-1}$ for nickel. The mean forecast concentrations of these metals in the sediments of the designed reservoirs in the Kraków agglomeration area (Table 3), based on the determination of lead, cadmium and nickel content in water, is higher than the mean content of these heavy metals in the six operated reservoirs. Three designed reservoirs - Piekary, Tonie and Janowice - are the exception, where the forecast mean concentration of nickel is smaller than 
the mean content of this metal in the six operated reservoirs, which is $22.1 \mathrm{mg} \mathrm{kg}^{-1}$.

Due to mean concentrations of the examined heavy metals in waters of four streams located in the urban agglomeration of Kraków, it can be stated that the content of these metals in water does not constitute a major hazardous pollution. On the other hand, the estimated heavy metal pollution of the sediments of the designed reservoirs in the Kraków agglomeration area, based on the established correlation relationship between heavy metal concentrations in the inflows to the six examined small reservoirs and metal concentrations in the sediments of these reservoirs, indicate the possibility of accumulating significant amounts of lead, cadmium and nickel in the sediments of these reservoirs. The calculated geoaccumulation index ( $\mathrm{I}_{\text {geo }}$ ) according to Müller [43] indicates that these sediments can be from unpolluted to moderately polluted due to the mean concentration of lead and nickel. The mean concentration of nickel in the sediment of the designed reservoir Węgrzce, which classifies the sediment as moderately polluted, also exceeds the TEL value. This means that levels of this metal in the sediment of this reservoir will exceed the toxic effect on aquatic organisms. The TEL value will be exceeded by the mean concentrations of cadmium accumulated in the sediment of each of the planned reservoirs. Taking into account the predicted maximum concentrations of lead, cadmium and nickel in the sediment of the planned reservoirs, it can be concluded that, according to the geoaccumulation index, these sediments can be described as moderately polluted or even strongly to extremely polluted. In this assessment, taking into account the EQS criteria [21], the maximum concentrations of the analyzed heavy metals will exceed values from TEL to SEL, above which a toxic effect on aquatic organisms will occur. The proposed correlation dependencies will be verified after the construction and after a sufficiently long operation period of the planned reservoirs, allowing sediment sampling from these reservoirs.

\section{Acknowledgments}

The authors would like to thank Dean of the Faculty of Environmental Engineering and Land Surveying, University of Agriculture in Krakow, for financial support. We thank the anonymous reviewers for their constructive comments which helped to substantially improve the manuscript.

\section{Author Contributions}

B.M. (Professor) conducted all the experiments and wrote the manuscript. A.C. (Associate Professor) conducted all the experiments and revised the manuscript

\section{References}

1. Jurik L, Húska D, Halászová K, Bandlerová A. Small water reservoirs - sources of water problems? J. Ecol. Eng. 2015;16(4): $22-28$.
2. Sawunyama T, Senzanje A, Mhizha A. Estimation of small reservoirs storage capacities in Limpopo River Basin using geographical information system (GIS) and remotely sensed surface areas: Case of Mzingwane catchment. Phys. Chem. Earth 2006;31:935-943.

3. Programme of Small Retention of the Małopolski District. Project of Marshal Office of Małopolski District and Land Melioration and Water Units Board of Małopolski Province in Cracow; Cracow, Poland; 2004. p. 1-47. (In Polish).

4. Batuca GD, Jordaan MJJr. Silting and Desilting of Reservoirs A.A.Balkema, Rotterdam, The Netherlands; 2000. p. 1-358.

5. White P, Labadz JC, Buchter DP. Sediment yield estimation from reservoir studies: an appraisal of variability in the southern Pennines of the UK. In: Erosion and sediment yield: global and regional perspectives. IAHS publication, 1996; 236, p. 163-173.

6. Neto IEL, Wiegand MC, de Araújo JC. Sediment redistribution due to a dense reservoir network in a large semi-arid Brazilian basin. Hydrol. Sci. J. 2011;56:319-333.

7. Verstraeten G, Poesen J. Estimating trap efficiency of small reservoirs and ponds: methods and implications for the assessment of sediment yield. Prog. Phys. Geogr. 2000;24(2):219-251.

8. Michalec B. Appraisal of silting intensity of small water reservoirs in the Upper Vistula river basin. In Scientific Fascicles; Agricultural University Cracow, Kraków, Poland; 2008. p. 1-193. (In Polish).

9. Jebari S, Berndtsson R, Bahri A, Boufaroua M. Spatial soil loss risk and reservoir siltation in semi-arid Tunisia. Hydrol. Sci. J. 2010;55:121-137.

10. Ndomba PM. Developing sediment yield prediction equations for small catchments in Tanzania. In: Advances in data, methods, models and their applications in geoscience. Dongmei C, eds. InTech; 2011. p. 241-260.

11. Radoane M, Radoane N. Dams, sediment sources and reservoir silting in Romania. Geomorphology 2005;71:112-125.

12. Vanzela LS, Grecco DL, Neto JN, Santos GO. Evaluation of sediment production and siltation in a small earth dam in Fernandopolis. SP. Eng. Agríc. Jaboticabal. 2014;34(95):912-924.

13. Hiller E, Jurkovic L, Sutriepka M. Metals in the Surface Sediments of Selected Water Reservoirs, Slovakia. Bull. Environ. Contam. Toxicol. 2010;84:635-640.

14. Findık Ö, Turan MA. Metal Concentrations in Surface Sediments of Beyler Reservoir (Turkey). Bull. Environ. Contam. Toxicol. 2012;88:193-197.

15. Chon HS, Ohandja DG, Voulvoulis N. The role of sediments as a source of metals in river catchments. Chemosphere 2012;10:1250-1256.

16. Islam MS, Ahmed AK, Raknuzzaman M, Habibullah-Al-Mamut $\mathrm{M}$, Islam MK. Heavy metal pollution in surface water and sediment: A preliminary assessment of an urban river in a developing country. Ecol. Indic. 2015;48:282-291.

17. Kanownik W, Kowalik T, Bogdał A, Ostrowski K, Rajda W. Quality and usable value of waters outflowing from catchment of small reservoirs planned in the Krakow area. Monograph, Publishing House of the University of Agriculture in Krakow. Poland; 2011. p. 1-110.

18. Qin HP, He KM, Fu G. Modeling middle and final flush effects 
of urban runoff pollution in an urbanizing catchment. J. Hydrol. 2016;534:638-647.

19. Zhang P, Cai Y, Wang J. A simulation-based real-time control system for reducing urban runoff pollution through a stormwater storage tank. J. Clean. Prod. 2018;183:641-652.

20. Sakson G, Brzezinska A, Zawilski M. Emission of heavy metals from an urban catchment into receiving water and possibility of its limitation on the example of Lodz city. Environ. Monit. Assess. 2018;190:281.

21. Burton GAJr. Sediment quality criteria in use around the world. Limnology 2002;3(2):65-76.

22. Xiao R, Bai J, Gao H, Wang J, Huang L, Liu P. Distribution and contamination assessment of heavy metals in water and soils from the college town in the Pearl River Delta, China. Clean-Soil Air Water 2012;40:1167-1173.

23. Liu X, Li G, Liu Z, Guo W, Gao N. Water pollution characteristics and assessment of lower reaches in Haihe River basin. Proc. Environ. Sci. 2010;2:199-206.

24. Sojka M, Jaskuła J, Siepak M. Heavy Metals in Bottom Sediments of Reservoirs in the Lowland Area of Western Poland: Concentrations, Distribution, Sources and Ecological Risk. Water 2019;11(56):1-20.

25. Shaheen SM, Rinklebe J. Geochemical fractions of chromium, copper, and zinc and their vertical distribution in floodplain soil profiles along the Central Elbe. Geoderma 2014;228-229: 152-159.

26. Gao L, Wang A, Li A, Chen J. Bioavailability and toxicity of trace metals $(\mathrm{Cd}, \mathrm{Cr}, \mathrm{Cu}, \mathrm{Ni}$, and $\mathrm{Zn}$ ) in sediment cores from the Shima River, South China. Chemosphere 2018;192:31-42.

27. Wang X, Zhang L, Zhao Z, Cai Y. Heavy metal pollution in reservoirs in the hilly area of southern China: Distribution, source apportionment and health risk assessment. Sci. Total Environ. 2018;634:158-169.

28. Xia F, Qu L, Wang T, et al. Distribution and source analysis of heavy metal pollutants in sediments of a rapid developing urban river system. Chemosphere 2018;207:218-228.

29. Bhowmik AK, Alamdar A, Katsoyiannis I, et al. Mapping human health risks from exposure to trace metal contamination of drinking water sources in Pakistan. Sci. Total Environ. 2015;538: 306-316.

30. Bąk Ł, Szeląg B, Sałata A, Studziński J. Modeling of Heavy Metal (Ni, Mn, Co, Zn, Cu, Pb, and Fe) and PAH Content in Stormwater Sediments Based on Weather and Physico-Geographical Characteristics of the Catchment-Data-Mining Approach. Water 2019;11:626.

31. Yao H, Zhuang W, Qian Y, Xia B, Yang Y, Qian X. Estimating and Predicting Metal Concentration Using Online Turbidity Values and Water Quality Models in Two Rivers of the Taihu Basin, Eastern China. PLoS ONE 2016;11(3):e0152491.

32. Green MO. Predicting decadal-scale estuarine sedimentation for planning catchment development. IAHS Publication 2008;325:550-558.

33. Ayaz M, Khan N-U. Forecasting of heavy metals contamination in coastal sea surface water of the Karachi harbor area using neural network approach. Nat. Environ. Pollut. Technol. 2019;18(3):719-733.

34. Michalec B, Lenart-Boron A, Wałęga A, Cupak A. The evaluation of heavy metal content in water and sediments of small reservoirs in light of various environmental quality regulations. J. Environ. Sci. Health A. 2014;49(7):827-832.

35. Kanownik W, Kowalik T, Bogdał A, Ostrowski K. Quality categories of stream water included in a Small Retention Program. Pol. J. Environ. Stud. 2013;22(1):159-165.

36. Michalec B. Qualitative and quantitative assessment of sediment pollution with heavy metals of small water reservoirs. In: Soil Health and Land Use Manage. Hernandez-Soriano MC ed. InTech. 2011:255-278.

37. Szarek-Gwiazda E. Factors influencing the concentrations of heavy metals in the Raba River and selected Carpathian dam reservoirs. Studia Naturae. 2013;60:1-146.

38. Baran A, Tarnawski M, Urbański K, Klimkowicz-Pawlas A, Spałek A. Concentration, sources and risk assessment of PAHs in bottom sediments, Environ. Sci. Pollut. Res. 2017;24(29): 23180-23195.

39. Regulation of the Minister of Environment of 11 December 2017 on the quality of water intended for human consumption. Polish Minister of Health. Journal of Laws of the Republic of Poland, No. 2294. Warsaw, Poland; 2017. (in Polish).

40. MacDonald DD, DiPinto LM, Field J, Ingersoll CG, Long ER, Swartz RC. Development and evaluation of consensus-based sediment effect concentrations for polychlorinated biphenyls (PCBs). Environ. Toxicol. Chem. 2000a;19:1403-1413.

41. MacDonald DD, Ingersoll CG, Berger TA. Development and evaluation of consensus-based sediment quality guidelines for freshwater ecosystems. Archives of Environ. Toxicol. Chem. 2000b;39:20-31.

42. Edokpayi J, Odiyo JO, Popoola OE, Msagati T. Assessment of Trace Metals Contamination of Surface Water and Sediment: A Case Study of Mvudi River, South Africa. Sustainability 2016;8:135.

43. Müller G. Die Schwermetallbelastung der Sedimenten des Neckars und seiner Nebenflüsse. Chemiker-Zeitung 1981;6:57-168.

44. Turiekian KK, Wedepohl KH. Distribution of the elements in some major units of the earth's crusts. Bull. Geol. Soc. Am. 1961;72:175-192.

45. Stanisz A. Accessible statistics course. StatSoft, Kraków, Poland; 2007. p. 733-868. (in Polish).

46. US Environmental Protection Agency, Risk Assessment, Management and Communication of Drinking Water Contamination, EPA-625/4-89/024, Office of Drinking Water, Washington DC; 1990.

47. Directive 2013/39/EC of the European Parliament and of the Council of 12 August 2013 amending Directives 2000/60/EC and 2008/105/EC as regards priority substances in the field of water policy of the European Parliament and of the Council, L 222, Strasbourg; 2008. p. 1-17.

48. Wang J, Da L, Song K, Li BL. Temporal variations of surface water quality in urban, suburban and rural areas during rapid urbanization in Shanghai, China. Environ. Pollut. 2008;152; 387-393.

49. Hutchins MG. What impact might mitigation of diffuse nitrate pollution have on river water quality in a rural catchment? J. Environ. Manage. 2012;109:19-26.

50. Mouri G, Shinoda S, Oki T. Assessing environmental improve- 
ment options from a water quality perspective for an urbanerural catchment. Enviro. Model. Softw. 2012;32:16-26.

51. Bakarat A, El Baghdadi M, Meddah R, Rais J, Nadem S, Afdali M. Evaluation of water quality in open channels flowing through Beni-Mellal City (Morocco). J. Water Land Dev. 2013;19:3-11.

52. Policht-Latawiec A, Bogdał A, Kanownik W, Kowalik T, Ostrowski K, Gryboś P. Quality and usable values of small flysch river water. Annu. Set Environ. Protect. 2014;16(1): 546-561. (in Polish).

53. Bogdał A, Kowalik T, Ostrowski K, Skowron P. Seasonal variability of physicochemical parameters of water quality on length of Uszwica river. J. Ecol. Eng. 2016;17 (1):161-170.

54. Tarnawski M, Baran A, Koniarz T. The effect of bottom sediment supplement on changes of soil properties and on the chemical composition of plants. Geol. Geophysics Environ. 2015;41(3): 285-292.

55. Saleem M, Iqbal J, Akhter G, Shah MH. Fractionation, bioavailability, contamination and environmental risk of heavy metals in the sediments from a freshwater reservoir. Pakistan. J. Geochem. Explor. 2018;184:199-208.

56. Baran A, Tarnawski M. Assessment of heavy metals mobility and toxicity in contaminated sediments by sequential extraction and a battery of bioassays. Ecotoxicology 2015;24(6):1279-1293.

57. Sałata A, Bąk Ł, Chmielowski K, Rabajczyk A. Metal pollution of sediments in small water reservoirs in the Kielce Highland (South Eastern Poland). Archives of Environmental Protection 2019;45(2):12-21.

58. Michalec B, Tarnawski M. Appraisal of bottom sediment pollu- tion with heavy metals of water reservoirs located in South Poland. Arch. Environ. Protect. 2009;35(3):73-85.

59. Tarnawski M, Baran A, Michalec B. Assessment of metal leachability and toxicity from sediment potentially stored on land. Water SA 2015;41(5):606- 613.

60. Gao H, Bai J, Xiao R, Liu P, Jiang W, Wang J. Levels, sources and risk assessment of trace elements in wetland soils of a typical shallow freshwater lake, China. Stoch. Environ. Res. Risk. Assess. 2013;27:275-284.

61. Pobi KK, Satpati S, Dutta S, Nayek S, Saha RN, Gupta S. Sources evaluation and ecological risk assessment of heavy metals accumulated within a natural stream of Durgapur industrial zone, India, by using multivariate analysis and pollution indices. Appl. Water Sci. 2019;9(3):58.

62. Munk L, Faure G. Effects of pH fluctuations on potentially toxic metals in the water and sediment of the Dillon Reservoir, Summit County, Colorado. Appl. Geochem. 2004;19:1065-1074.

63. Calmano W, von der Kammer F, Schwartz R. Characterization of redox conditions in soils and sediments: heavy metals. In: Soil and Sediment remediation. Lens P, Grotenhuis T, Malina G, Tabak H, eds. Great Britain: IWA Publ; 2005. p. 102-120.

64. Kulbat E, Sokołowska A. Methods of Assessment of Metal Contamination in Bottom Sediments (Case Study: Straszyn Lake, Poland). Arch. Environ. Contam. Toxicol. 2019;77:605-618.

65. Cappuyns V, Swennen R. Kinetics of element release during combined oxidation and $\mathrm{pH}$ stat leaching of anoxic river sediments. Appl. Geochem. 2005;20:1169-1179. 